\title{
A SOVIET PASTORAL
}

Who thought that peaceful vistas cannot be A fine arena for catastrophe?

Andrey Egunov published Beyond Tula: A Soviet Pastoral in 1931, under the pseudonym Andrey Nikolev. ${ }^{2}$ This novel invites the reader to take an outrageously tongue-in-cheek jaunt through the earnestly boring and unintentionally campy world of the Socialist Realist "production novel."3 It has a transparently insignificant plot: a young writer from the city comes to visit his engineer friend in the country for a couple of days, and everything ends by the grave of Leo Tolstoy. The novel's homoeroticism is obvious, yet unobtrusive enough to have slipped past the censors. The dialogues are snappy and darkly clever, and strange and terrible things happen in between the cheerful rompings and silly flirtations. As one critic put it, the novel is "gourmandise-in its hedonism and perfectionism; and it possesses a negative charm-for there is abhorrence and terror hidden behind the clowning and the brilliance of its style."4 Egunov himself commented elsewhere on the paradoxical capacity of goofy antics to

1 "Kto vydumal, chto mirnye peizazhi/Ne mogut byt" arenoi katastrof?" From Mikhail Kuzmin, "The Trout Breaks the Ice" (1929).

2 Egunov published Tula under the pseudonym Andrey Nikolev, which refers to the minor eighteenth-century Russian poet Nikolay Nikolev (1758-1815). With a nod to literary-historical precedent with Russian writers like Alexander Bestuzhev-Marlinsky and Mikhail Saltykov-Shchedrin, I refer to him as Egunov-Nikolev in connection with Beyond Tula, but just Egunov elsewhere.

3 Socialist Realism - which strove to "depict reality in its revolutionary development" was the official artistic policy in the Soviet Union from 1934 to perestroika. The production novel was a popular early genre-its plot reflected early Soviet efforts to rapidly industrialize, modernize, and improve the nation's production of goods and raw materials.

4 Aleksandr Zhitenev, “Antre Liamer \& Faiginyu," Novaia real' nost' no. 29 (2011). 
convey both the "agony of experience" and the metaphysics buried within language itself. ${ }^{5}$

Egunov was born September 26, 1895, in Ashgabat, the present-day capital of Turkmenistan. His family moved to St. Petersburg in 1905. There young Andrey studied at the prestigious Tenishev Gymnasium, alongside other famous-literati-to-be like Osip Mandelstam and Vladimir Nabokov. He graduated from St. Petersburg State University in 1918 with a degree in classics and subsequently embarked on postgraduate studies in Russian literature, but the postrevolutionary reorganization of the university system caused him to be excluded (as the son of an imperial officer) after one year of study. Egunov found work teaching at the new "workers' faculties" ( $r a b$ fak) and as a private tutor. He continued his work in classical philology and was active as a translator; his translation of Plato's Laws was published in 1923 and is still read today. ${ }^{6}$

Beginning in the early 1920s, Egunov was also a member of a more informal collective of translators and friends, known as ABDEM (the acronym is made from the first letters of the participants' last names). The group collectively translated and published The Adventures of Leucippe and Clitophon, by Achilles Tatius (Gosizdat, 1925) and Aethiopica (or Theagenes and Chariclea), by Heliodorus of Emesa (Academia, 1932). These worksearly romances or "novels" - were considered frivolous and met a lukewarm reception among the contemporary scholarly community. But the latter half of the 1920s also saw the flowering of Egunov's own literary career: between 1928 and 1932 he wrote most of the poems in the cycle "Elysian Joys," the first draft of the long poem "Objectless Youth," and the novel Beyond Tula. Another novel, Vasily Island (Vasilii Ostrov), was written in 1929 but lost along the way. During this period, Egunov took part in the lively artistic and literary life of 1920s Leningrad; in particular, he was friendly with the OBERIU poets (especially Konstantin Vaginov) and with Mikhail Kuzmin and his circle. Egunov was arrested in 1933 under suspicion of anti-Soviet activity, much as the OBERIU poets Daniil Kharms and

5 Andrei Egunov-Nikolev, "Osmyslenie," in Bespredmetnaia iunost' (Moscow: Intrada, 2009), 39-40.

6 See the Egunov bibliography at the end of the book for a more complete list of publications. 
Alexander Vvedensky had been a few years earlier. ${ }^{7}$ He was sentenced to three years' internal exile in Siberia. ${ }^{8}$

With a nod to his work as a classics scholar, Egunov-Nikolev subtitled his novel "A Soviet Pastoral": one of the many source texts for Beyond Tula is a second-century Greek romance written in the form of a travelogue, The Incredible Wonders beyond Thule of Antonius Diogenes. ${ }^{9}$ As a romance (or adventure novel), Diogenes' work belonged to the "low" genres like comedy or satire. Egunov-Nikolev had a number of motivations for affiliating his Beyond Tula with both the pastoral and the classical romance. Aware that nothing about his writing style fell in line with the increasingly rigid cultural politics of the late 1920s and early 1930s-the ever-greater emphasis on the unambiguous heroism and epic historicism that would soon become Socialist Realism-Egunov-Nikolev took a neat sidestep by flaunting the banal and fantastical aspects of his work.

At the same time, the novel also features an exaggeratedly ideal protagonist, the young engineer Fyodor, who acts out a canonical early Soviet plotline: the struggle of the new, technologically advanced Soviet way of life with the prejudices and ignorance of the unenlightened peasants. Serious Fyodor-who at twenty-two claims he "can't remember life before the revolution"-is thus juxtaposed with the utterly irreverent Sergey, who at twenty-six is a jaded vestige of the ancien régime (Fyodor's mother, an opera singer who shows up halfway through the novel, is an even more outrageous vestige). Meanwhile, Fyodor and Sergey's romantic involvement conspicuously undermines the contrast between their worldviews. A similarly ironic and uneasy relationship to the new requirements in life and literature can be observed in other early Soviet experimental fiction such as Yuri Olesha's Envy or Konstantin Vaginov's cult classic Goat Song (both

7 The OBERIU (Union of Real Art), a group of experimental absurdist poets, existed for a few years in the late 1920s and early 1930s.

8 Egunov was arrested under suspicion of involvement with the controversial thinker/ ideologue Ivanov-Razumnik; in fact, he was not involved with Ivanov-Razumnik, but was denounced following the arrest of some other members of Octopus, a literary group he occasionally attended.

9 The only existing account of the work comes from Photius (http://www.tertullian.org/ fathers/photius_copyright/photius_04bibliotheca.htm), who praises it highly for its vivid narration, its clarity, and the gracefulness of its descriptions. 
published in 1927-28). A certain kind of literary homoeroticism was not unusual for this time period-contemporaries of Egunov like Olesha and Isaac Babel incorporated the early Soviet cult of the male body and sexuality into their prose, at times quite provocatively. Even as Egunov-Nikolev's novel shares some aesthetic positions with these practitioners of literary Ornamentalism, the romantic plot in Beyond Tula is more subtle and realistic, and it evokes some of the languid decadence, aesthetic excess, and loose sexual politics of the prerevolutionary Russian Symbolists.

Another source of tension in Beyond Tula is the unresolved imbalance between the real world and the world of (literary) fantasy. The contradictions begin right away, with the title: Tula is a provincial Russian city known for its samovars, but Thule calls up the medieval geographical designation ultima Thule, "a distant unknown region; the extreme limit of travel and discovery." Next, the word "Soviet" in the subtitle points to a very concrete time and place, in a way that contrasts sharply with the ahistorical mood of the "pastoral." In the world of the novel, however, the Soviet Union is a mostly fantastical construct, insofar as the action unfolds in a timeless countryside touched by Soviet-led progress only in menacing ways. At the same time, this rural space is in a state of rapid change, as the Soviet mining industry literally undercuts the older pastoral ways of life. The Tula district and the nearby Tolstoy estate of Yasnaya Polyana are, meanwhile, real geographical locations; their old world ways are contrasted in turn to the progress and industrialization of real modern cities like Moscow and St. Petersburg/Leningrad (or its stand-in, Sergey's hometown of Peterhof). Contrasts like this point to potential utopias, but these are undermined as soon as they emerge. Fyodor's mother and Sergey have escaped the big city in search of a pastoral paradise, but they are unable to appreciate the rustic charm of the countryside.

Egunov was close with the modernist poet Mikhail Kuzmin, and Kuzmin's masterful poem "The Trout Breaks the Ice" (1925-28) is a major intertext for the novel's motifs and plot development. But Egunov was younger than Kuzmin and more rooted in the new Soviet reality; he adopted a necessarily ironic stance toward the ideal that humanity could be improved through love or art, even as he mocked the burgeoning Socialist Realist aesthetic. Along these lines, the novel's play with different registers of Soviet and pre-Soviet language (consider the persistent musical conflict between operas, sentimental romance songs, and rousing Soviet youth anthems), the idiosyncratic numbering of chapters and transitions between them, and the abrupt 
and somewhat absurdist "ending," recall some of the devices characteristic of poets like Kharms, Vvedensky, and Vaginov. At times the cacophony even points toward the radical language experiments of Andrey Platonov.

Egunov's subversive attitude toward genre and literary tradition extended to standing up for the artist's right to live outside the norms of society and not contribute to its material well-being. By presenting his novel as light and frivolous, he freed himself from expectations of a weighty moral message, which in turn allowed for the interpolation of any number of more and less ambiguous meanings in the novel's plot and the relationships between its characters, including the subtle but unmistakable darkness and tragedy present throughout the novel.

After serving out his sentence of exile, Egunov remained in Tomsk until 1938, when he moved to Novgorod and began commuting to Leningrad to teach at the state university. ${ }^{10}$ In 1941, Novgorod was occupied by the Germans, and Egunov was taken as a captive to Neustadt in northern Germany, where he was kept in a labor camp for the remainder of the war. After the Allied victory in 1945, he and his mother moved to Berlin, where he taught German to Soviet officers until he was forcibly repatriated in 1946. He is known to have taught both Soviet and American soldiers and would have been considered a traitor. In any event, in 1946 he was repatriated and, like many former prisoners of war, immediately sentenced to ten years of correctional labor, which he carried out in various far-flung regions of the Soviet Union. He was rehabilitated in 1956 (just a few months before completing his sentence) and finally returned to Leningrad. He had been married to Tamara Danilova since 1930, but they had barely ever lived in the same city; she died in 1955, and they had no children. In order to receive a permit to live in Leningrad, he married his friend Anna Gipsi in 1956. Egunov spent the years left to him once again working on translations and classical philology in a number of Leningrad literary institutions. $\mathrm{He}$ died in 1968 and was buried in a cemetery outside Leningrad.

Egunov-Nikolev's stylistic play creates endless headaches for the translator. Romance songs, ditties, and folk sayings are, language aside,

10 Exiles were not permitted to hold residence permits in large cities. Novgorod is a fourhour train ride from Petersburg. 
notoriously difficult to translate into a different cultural context; the distinct speech modes of the various protagonists, which subtly convey their social status and attitude toward societal change, are hardly easier. And yet the novel's basic orientation is one of fundamental indeterminacy; this is reflected in its play with doubles, names, and genders. For example, when Fyodor or Sergey is referred to as a Shade (in Russian, ten', a feminine noun), all of their actions in this guise are grammatically colored by the Shade's femininity. By contrast, when Fyodor's boss is dubbed "the Adored Management," he becomes grammatically neutered, an "it" (nachal'stvoono) and hence somewhat dehumanized; this is even more the case with the character known as the Spawn (of Hell). A dehumanizing effect is also created through the device of multiplication, as in Sergey's musing on the three characters' identical speech or the multiple references to "both Fyodors" or "Dunya, and the other Dunya." Sergey ponders at one point, The co-op operator, Syssoyich Sazykin, and the Adored-they all speak exactly the same language. How can we know-maybe they aren't three people at all, but just one.

Manipulating names, genders, and character trajectories is, however, a perfectly ordinary thing for a writer to do. Like his friend Konstantin Vaginov, Egunov embraces this kind of writerly metacommentary, although he limits these pronouncements to his characters, particularly the writercharacter Sergey:

Sergey did some mental calculations: if this line goes this way, then that one goes the other way. Right. But then they intersect here. No, that doesn't work. This line should slant down and create a new plane. And I bend it here like this. Fyodor should really be turned into a woman. And then he can be Signora Stratelates. And Leocadia can be a man, an Italian with the last name Leocado.

These ruminations even include several gestures toward the increasingly difficulties faced by writers in the late 1920s and early 1930s:

"There always has to be some kind of sumptuous woman in the spotlight. [...] But endow her with every possible perfection: young, beautiful, attractive, a brilliant public figure, committed to building a new world. [. . .] But make sure the protagonist has some flaws: under Leocadia's influence, he'll rid himself of them." [...]

"And Fyodor is the ideal engineer?"

"Why not? But bring in a couple of negative types: the local priest, the local kulak. Don't forget that everything is happening in the immediate vicinity of 
Yasnaya Polyana. All of your characters should be reading Tolstoy, but the negative ones should be reading his religious nonsense." [.. .]

"[. . . ] it would be even better if you made the whole thing into a historical novel. You can leave in the mines, but make it all happen under Ivan the Terrible-after all, they were mining this area back then, too. It'll be great and no one will get offended."

The last comment is both poignant and ominous, since many Soviet writers beginning in the late 1920s and early 1930s (from Aleksey Tolstoy to Yuri Tynianov) did find that writing historical fiction was safer than writing about contemporary life. As Lydia Ginzburg wrote at the time, "For many people now, historical novels and children's books are a means of writing under one's breath [vpolgolosa]."11

Although it was published in the official press, Beyond Tula would be Egunov's first and last publication of nonscholarly or translated work. ${ }^{12}$ Egunov was one of the first in a long tradition of semiofficial Soviet writers; even in the 1920s, many writers whose work did not mesh well with official Soviet aesthetic standards were beginning to give up on official publication, to write "for the desk drawer," for small groups of friends, or just for themselves. Beyond Tula was published largely thanks to the friendly assistance of Konstantin Fedin, a prominent literary figure at the timewithout Fedin's intervention, a novel like this would never have made it past the increasingly virulent political, aesthetic, and moral censors. Even after being reprinted in the Wiener Slawistischer Almanach series in 1993 (edited by Gleb Morev), the novel remained little known, even to specialists of Russian literature. It has yet to be republished in Russia, although the text of the novel was published in the debut issue of the journal Russian Prose (Russkaia proza [A]) in 2011, accompanied by some supplemental essays. None of Egunov's work has been translated into English before now.

Ainsley Morse

Riverside, $C A$

April 2018

11 Lidiia Ginzburg, Zapisnye knizhki, vospominaniia, esse (St. Petersburg: Iskusstvo-SPB, 2002), 79.

12 It would be his only official publication for decades to come. After decades spent in prison camps and his eventual rehabilitation in the 1960s, Egunov managed to publish some scholarly articles and a single monograph. See the bibliography for more information. 